\title{
前立腺肥大症に対する温熱療法の臨床成績
}

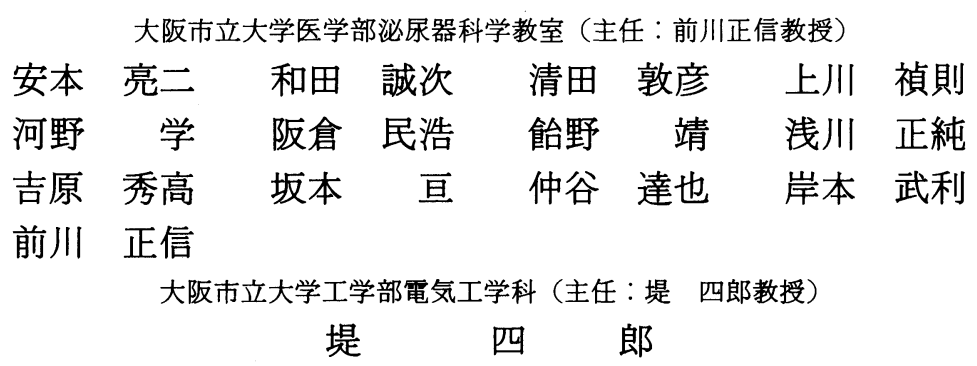

\section{HYPERTHERMIC TREATMENT IN PATIENTS WITH BENIGN PROSTATIC HYPERTROPHY}

\author{
Ryoji Yasumoto, Seiji Wada, Atsuhiko Kiyota, Sadanori Kamikawa, Manabu Kawano, \\ Tamihiro Sakakura, Yasuhi Ameno, Masazumi Asakawa, Hidetaka Yoshihara, \\ Wataru Sakamoto, Tatsuya Nakatani, Taketoshi Kishimoto \\ and Masanobu Maekawa \\ Department of Urology, Osaka City University Medical School \\ (Director: Prof. M. Maekawa) \\ Shirou Tsutsumi \\ Division of Electronics, Osaka City University
}

Hyperthermic treatment was performed in 31 patients with benign prostatic hypertrophy (BPH). Eight patients of them had a urethral catheter because of urinary retention. The prostate was heated transrectally to $43 \sim 45^{\circ} \mathrm{C}$. The treatment consisted of 10 sessions of $60 \mathrm{~min}$. each. To evaluate this treatment, the following parameters were determined before, during and one week after the last hyperthermia session: subjective symptoms score, and residual urine volume, uroflowmetry and transrectal ultrasound of the prostate as objective data. Symptoms score improve in all patients. Of 8 patients with a catheter, the catheter could be removed from 4 patients. There was no significant change in prostate volume, but significant decreases of residual urine volume, and increases of maximum flow rate and mean flow rate were observed. No adverse reactions were seen. Judging from the above results, this treatment is considered to be useful for patients with $\mathrm{BPH}$.

Key words: hyperthermia, BPH, obstructive uropathy

要旨：Tecnomatix 社製経直腸的温熱療法装置 primus を用い, 30例の BPH についてその臨床成績を評

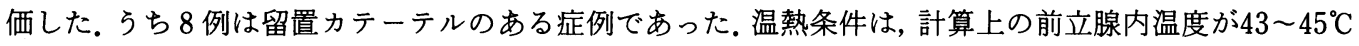
で60分間持続するように設定し合計10回行った。自覚症状をスコア值にして評価した結果, 留置カテー テルのない全症例に改善が観察された．留置カテーテルのあった 8 症例中 4 例（50\%）にカテーテル抜 去が可能であった．前立腺容積については治療前後で有意差は認められなかったが，残尿量に明らかな 減少傾向が観察された。最大尿流量率・平均尿流量率に明らかな改善が $26 \%$ に見られた。留置カテーテ ルのない22症例について他覚的改善度を調べてみると, 改善10例 (45\%), やや改善 6 例 (27\%), 不変 6 例（27\%）と，改善傾向を示した症例は $72 \%$ であった，合併症や副作用は見られず，有用率は63\%で あった。温熱機序についてはまだ不明な点があるが，この方法は前立腺肥大症に伴う排尿障害に対し試 みてもよい治療方法の一つと思われた。 キーワード：温熱療法, 前立腺肥大症, 排尿障害 


\section{I. 緒言}

前立腺肥大症に対する非観血的または保存的治療と

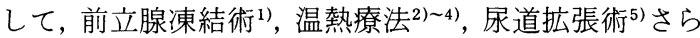
に尿道内ステント留置術副などがあげられている。こ のらち，温熱療法は電磁波で局所温度を高め，細胞の 増殖を抑制しょうと考兄られた新しい治療法である。 今回, 前立腺肥大症症例に対し, 経直腸的温熱療法装 置を用いた温熱療法を施行し，その臨床成績を自覚症 状ならびに他覚所見両面から評価したので報告する。

\section{II. 対象ならびに方法}

1. 対象について

対象の条件として，50歳以上の排尿障害を主訴とす る前立腺肥大症患者で, 自覚症状のスコア值（表 1) の合計が 10 点以上を示し, しかも他の観血的治療の困 難な症例や全身性合併症を有する症例を選択した。対 象の中には前治療として非ホルモン性治療剂が投与さ れておりその効果が不十分の症例も7例含まれてい た。 その平均年齢は73.5歳（54〜85歳）であった。

2. 温熱療法の装置と治療条件について

温熱療法に用いた装置は tecnomatix 社製の primusで, $915 \mathrm{MHz}$ の電磁波を発生するアンテナと アンテナ表面及び内部を冷却する装置, さらに温度管 理や治療全体の管理を行らコンピュータ装置からなっ ている(図 1)。治療条件としては, Yerushalmi らの 行っている条件を参考にして行った。すなわち，計算 上の前立腺内温度が $43 \sim 45^{\circ} \mathrm{C}$ を示したのち， 60 分間そ の温度が持続するよう設定した。なお，その設定温度 に達するには約 20 分間要するため，実際の治療時間は 80分を要した（図 2 )。

3. 経過観察項目と評価基準について
前述の条件で，温熱療法を原則として週 2 回，合計 10回行った。尿閉のため留置カテーテルのある症例で は治療中並びに治療終了後，カテーテルを拔去し，排 尿状態を観察すると共に，排尿可能ならばそのまま経 過観察とすることとした。経過中の観察項目ならびに 検査は表 2 に示すように行い, 自覚症状の変化はスコ ア值として算出し，他覚的検査として残尿測定，尿流 量測定，そして直腸診や前立腺超音波検査を行った。

評価基準として，自覚症状についてはその合計点数 が50\%以上改善した場合を著効，50から $25 \%$ までを有 効，25\%未満でも自覚症状の改善の見られたものをや や有効, 合計点数の変化のないものを無効, 合計点数 が増加したものを悪化と評価した。他覚所見の評価と して, 残尿量は $25 \%$ 以上減少しかつ前後の残尿量の差 が $30 \mathrm{ml}$ 以上の改善を示す場合を「改善」, $25 \%$ 以上の減 少を示すが前後の残尿量の差が $30 \mathrm{ml}$ 未満の改善を「や や改善」，それ以外を「不変」とした。一方，排尿機能 検査の評価として，個々の症例での一回排尿量が異な るため Siroky")のノモグラムを用いて改善度を評価し た。すなわち，ノモグラム上の SD 区分で 1 区分以上改 善した場合を「改善」，同一区分内での改善が見られた 場合を「やや改善」，SD 区分で 1 区分以上悪化した場 合を「悪化」，それ以外を「不変」として評価した。そ して，残尿量と尿流量検査成績の評価を用いて，他覚 所見の改善度とした。すなわち，いずれも改善を示し た場合を「改善」，いずれか一方しか改善が見られな かった場合を「やや改善」,やや改善・不変のいずれか である場合を「不変」とした。

主治医による主観的総合評価（以下主治医判定と略 す）以外に，自覚症状・他覚所見の改善度の組合せに

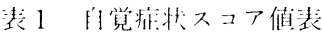

\begin{tabular}{|c|c|c|c|c|}
\hline 項目 & 0 点 & 1 点 & 2 点 & 3 点 \\
\hline 昼間排尿回数 & 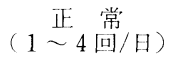 & $\begin{array}{c}\text { やや頻繁 } \\
(5 \sim 7 \text { 回/日) }\end{array}$ & 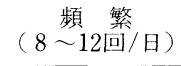 & $\begin{array}{c}\text { 極めて頻繁 } \\
\text { (13回/日以上) }\end{array}$ \\
\hline 夜間排尿回数 & ( 0 正回/常 & $\begin{array}{l}\text { やや頻繁 } \\
\text { (1回/日) }\end{array}$ & 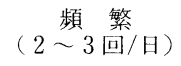 & $\begin{array}{l}\text { 極めて頻繁 } \\
\text { ( } 4 \text { 回/日以) }\end{array}$ \\
\hline 尿意逼迫感 & 無 し & 時々感じる & $\begin{array}{l}\text { 頻回に感じ, } \\
\text { まれに禁する }\end{array}$ & $\begin{array}{l}\text { つねに尿意を感じ, } \\
\text { 時々失禁する }\end{array}$ \\
\hline 尿線の状態 & 良 好 & 時々感じる & 減 弱 & 極めて減弱 \\
\hline 排尿遷延度 & 無 し & 時々遷延する & 頻回に遷延する & つねに遷延する \\
\hline 排尿贲然延度 & 無 し & 時々䓦延する & 頻回に阵延する & つねに䓦延する \\
\hline
\end{tabular}



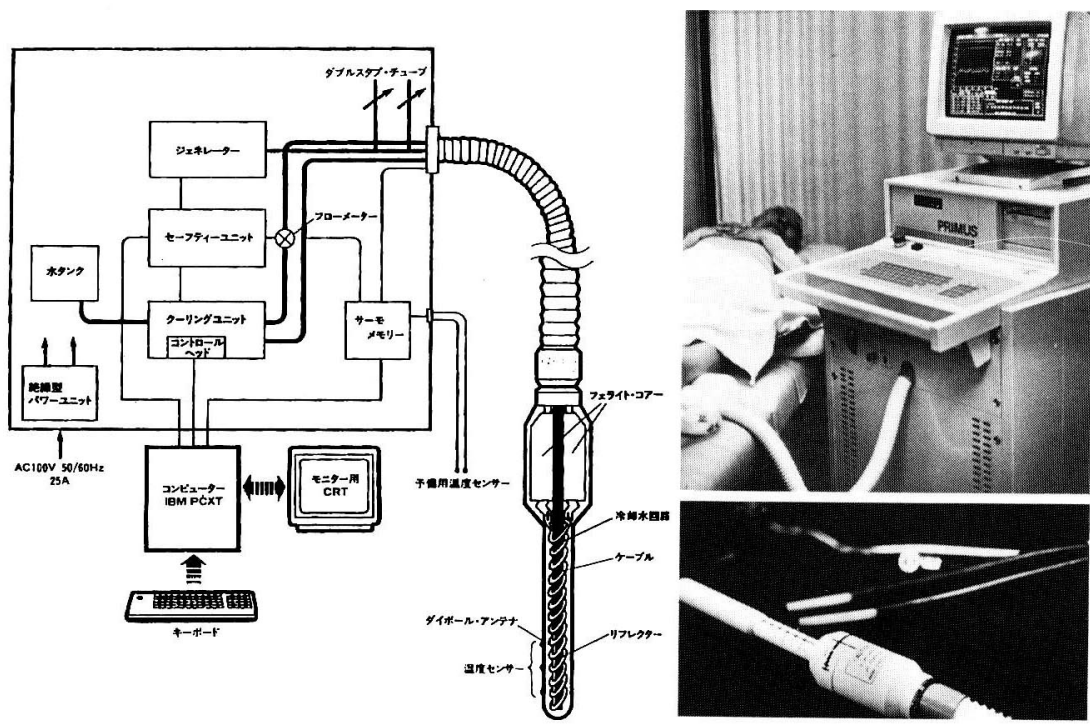

表 2 観察項目㧍よび観察時期

\begin{tabular}{|c|c|c|c|c|c|c|}
\hline \multirow{2}{*}{\multicolumn{2}{|c|}{ 観 察 項 目 }} & \multicolumn{2}{|c|}{ 鹳 } & 察 & \multicolumn{2}{|l|}{ 期 } \\
\hline & & 治療開始前 & 4 回目 & 5 回目 & 6 回目 & 治療終了時 \\
\hline \multicolumn{2}{|c|}{ 自覚拝状スコア } & 0 & 0 & & 0 & $\mathrm{O}$ \\
\hline \multirow{3}{*}{$\begin{array}{c}\text { 他検 } \\
\text { 賞査 } \\
\text { 的項 } \\
\text { 目 }\end{array}$} & 残 尿 測 定 & 0 & & & & O \\
\hline & 前立腺超音波検查 & 0 & & & & 0 \\
\hline & 尿流量測定 & 0 & & & & 0 \\
\hline \multicolumn{2}{|c|}{ 留置カテーテル拔去試行 } & 0 & & $\mathrm{O}$ & & $(\mathrm{O})$ \\
\hline
\end{tabular}

図 2 治療中の温度変化

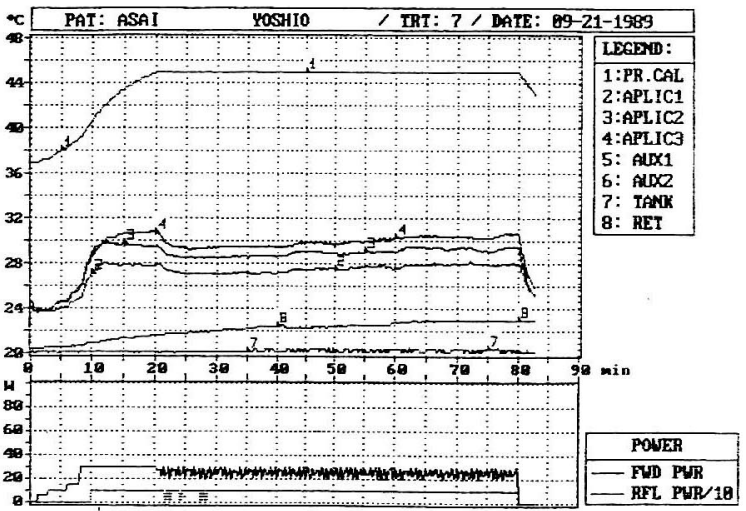

よる評価（以下委員会判定と略す）を行い，「有用」, 「やや有用」,「有用でない」の3 群に分け，「有用」以
上を有用度とした（図 3 ）。

\section{III. 成 績}

1. 総合評価について

遠距離のため通院が困難となりこの治療法の評価が できないまま中止となった 1 例を除いた30症例につい て評価した。主治医による総合評価としては有用が 12 例 $(40 \%)$ ，やや有用が14例 $(47 \%)$ ，有用でないが 4 例 (13\%) であった。一方，委員会判定による総合評 価としては，有用が19例 $(63 \%)$, やや有用が 7 例 (23\%)，有用でないが 4 例（13\%）と，主治医判定で 40\%，委員会判定で63\%の有用率であった（図 4 ）.

2. 自覚症状の変化について

自覚症状の変化をスコア值で評価すると, 排尿困難 を訴えた留置カテーテルのない22症例についてみる と, 治療開始後 2 ないし 3 回目からすでに改善傾向が 観察され治療回数が 4 回後には25\%減少（p<0.01）， 
6 回後には $33 \%$ 減少し $(p<0.01)$ 治療終了時には治療 開始前の值の $58 \%$ を示していた（p<0.05）。をた，排 尿に関し正常状態を示す症例の占める割合も治療につ れて多くなった(図 5 )。このように，治療後の自覚症 状の改善度は著効 5 例 (23\%), 有効17例 (77\%), 全 例有効以上を示した。

一方, 留置カテーテルのある 8 例中 4 例 $(50 \%)$ に カテーテルを抜去可能であったが，それら症例の自覚

図 3 総合評価（有用度）の判定基準

\begin{tabular}{|c|c|c|c|c|c|}
\hline 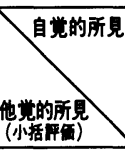 & $\begin{array}{l}\text { 著 } \\
\text { 効 }\end{array}$ & $\begin{array}{l}\text { 有 } \\
\text { 効 }\end{array}$ & $\begin{array}{l}や \\
\text { や } \\
\text { 真 } \\
\text { 就 }\end{array}$ & $\begin{array}{l}\text { 無 } \\
\text { 効 }\end{array}$ & $\begin{array}{l}\text { 德 } \\
\text { 化 }\end{array}$ \\
\hline 改 萻 & \multirow{2}{*}{\multicolumn{2}{|c|}{ 有有 }} & \multirow{2}{*}{ 结南 } & \multirow{3}{*}{\multicolumn{2}{|c|}{ 用 $\tau$}} \\
\hline やや改褰 & & & & & \\
\hline 不 変 & UIII & 牄解 & & & \\
\hline 悪 化 & & & & な し & \\
\hline
\end{tabular}

図 4 総合評価について

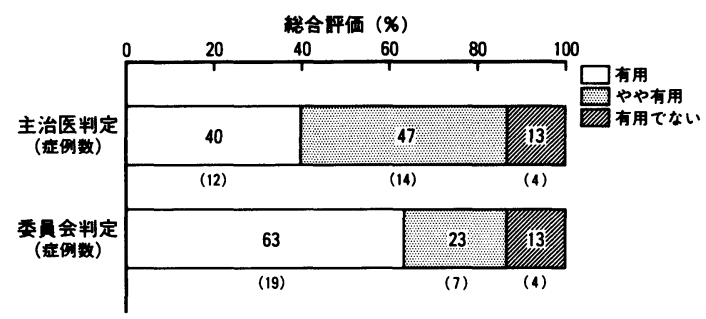

症状值は 1 例を除いて正常範囲内にあった。一方，抜 去できなかった残り 4 例のらち 2 例は留置カテーテル のまま，2 例には尿道内ステントを行い経過観察して いる.

3. 自覚症状項目別変化について

自覚症状の項目別変化についてみると，治療 4 回を 終了した時点では昼間排尿回数, 夜間排尿回数, 尿線 の状態，排尿遷延度，排尿苒延度，いずれの項目につ いても改善傾向が見られ，さらに治療を加兄ると夜間 排尿回数や排尿苸延度が良くなる傾向が観察された (図 6 ).

4. 他覚所見について

直腸診での前立腺の変化や経直腸的超音波前立腺断 層法による容積を治療前後比較してみると推計学的に 有意差は認められなかった。しかし，残尿量について は，治療前後明らかに減少する傾向が観察された（図 7 ). また，尿閉を示した 8 症例中留置カテーテルを抜

図 5 自覚症状の変化について

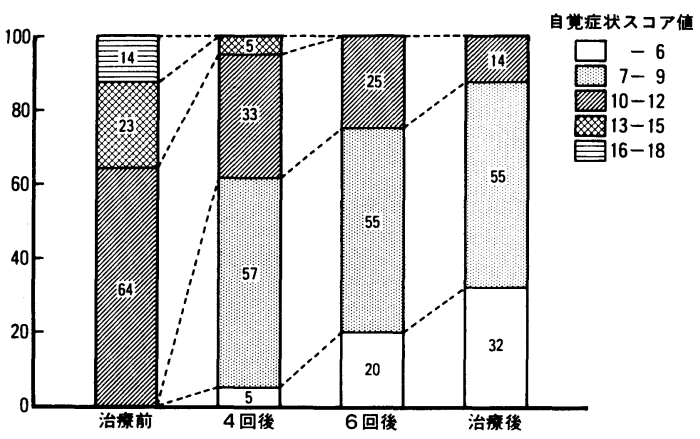

図 6 自覚症状項目別変化について

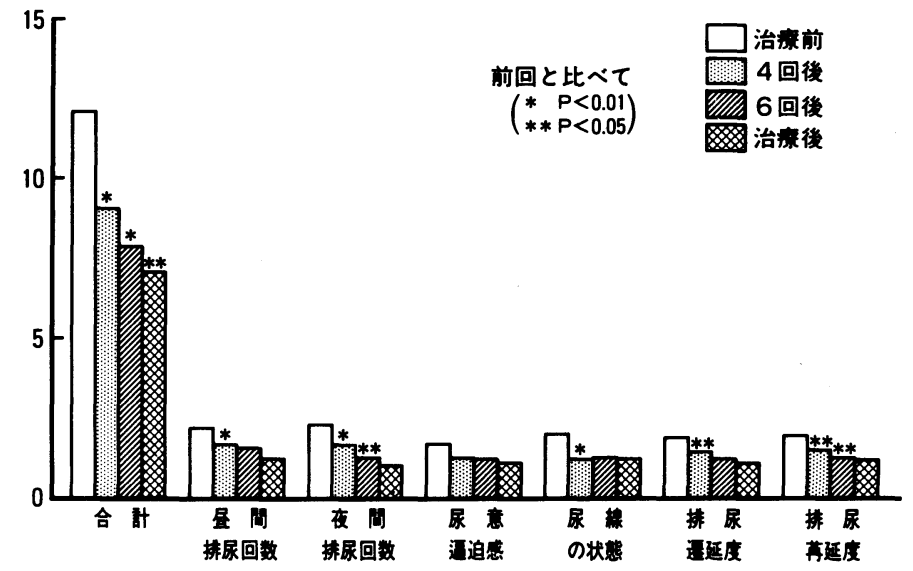


図 7 前立腺容積と残尿量の変化
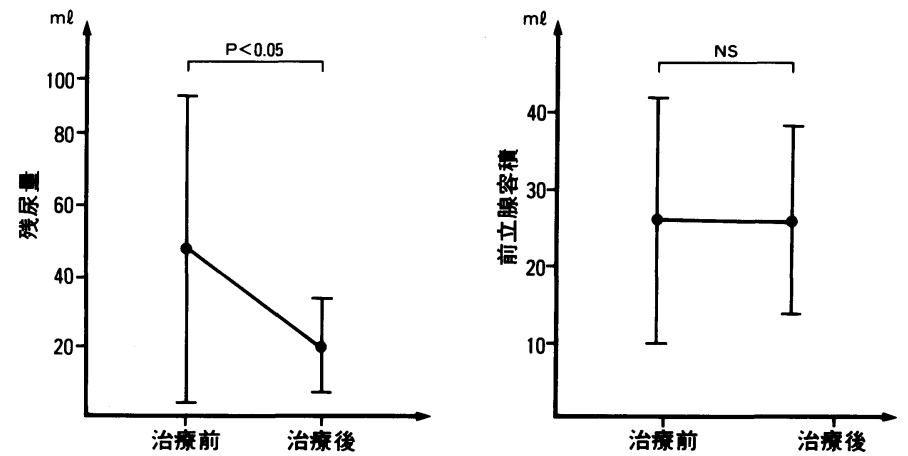

表 3 排尿機能検査の成績

\begin{tabular}{|c|c|c|c|c|c|c|}
\hline \multicolumn{3}{|c|}{ 最大尿流量率 MFR } & \multicolumn{2}{|c|}{ 平均尿流量率 AFR } & \multirow{2}{*}{$\begin{array}{l}\text { MFR z AFR の } \\
\text { 評価の組合わせ }\end{array}$} & \multirow{2}{*}{ 症例数 (\%) } \\
\hline 評 & 価 & 症例数 (\%) & 評＼cjkstart価 & 症例数 (\%) & & \\
\hline \multirow[t]{3}{*}{ 改 } & \multirow[t]{3}{*}{ 善 } & \multirow[t]{3}{*}{ 7例（37） } & \multirow[t]{3}{*}{ 改 善 } & \multirow[t]{3}{*}{ 7例（ $37 ）$} & 両方とも改善 & 5例 ( 26) \\
\hline & & & & & 改善 +やや改善 & 3例（16） \\
\hline & & & & & 改 善 + 悪 化 & 1例（5) \\
\hline \multirow{2}{*}{\multicolumn{2}{|c|}{ やや改善 }} & \multirow[t]{2}{*}{ 6例（ $32 ）$} & \multirow[t]{2}{*}{ やや改善 } & \multirow[t]{2}{*}{ 2例（11） } & 両方ともやや改善 & 1例 ( 5) \\
\hline & & & & & やや改善 +不変 & 3 例 ( 16$)$ \\
\hline 小 & 計 & 13例（69） & & 9例（48） & & 13例 ( 68 ) \\
\hline 不 & 変 & 6例 ( 31$)$ & 不 & 9例（47) & \multirow[t]{2}{*}{ 両方とも不変 } & \multirow[t]{2}{*}{ 6例 ( 32 ) } \\
\hline 悪 & 化 & 0 例（ 0$)$ & 悪 & 1例 ( 5$)$ & & \\
\hline 合 & 計 & 19例（100） & & 19例（100） & & 19例（100） \\
\hline
\end{tabular}

去しえた 4 症例での残尿量はそれぞれ $10 ， 80 ， 80 ， 79$ $\mathrm{ml}$ であった。

ノモグラムを用いて排尿機能検査の評価した結果, MFR については19症例中 7 例 (37\%) に改善が, 6 例 (32\%)にやや改善が観察され，全体的には13例，69\% に改善をみた。一方, AFRについてみると，19症例中 7 例 (37\%) に改善が，2 例（11\%）にやや改善が観 察され, 全体的には 9 例, 48\%に改善が観察された。 また, MFR や AFR の両者を組み合わせた評価では, 両者とも改善またはやや改善を示した症例それぞれが 5 例 (26\%)，1 例 ( $5 \%$ ）で，一方が改善で他方がや や改善または悪化を示した症例がそれぞれ 3 例 (16\%)，1例（5\%）であった。さらに，一方がやや 改善を示し，他方が不变を示した症例は 3 例（16\%） で，全体として13例（68\%）の症例に排尿機能検査上 の改善が観察された（表 3 ).

留置カテーテルのない22症例について他覚的改善度
を調べてみると, 改善10例（45\%), やや改善 6 例 (27\%), 不変 6 例 $(27 \%)$, 改善以上を示した症例 は $45 \%$ であった，留置カテーテルのある 8 症例につい てみると, 改善および不変はいずれも 4 例 $(50 \%)$ で あった。

5. 血液検査成績および副作用について

治療前の腎機能評価が正常を示す症例が大多数で あったが, 血中クレアチニン値が $1.5 \mathrm{mg} / \mathrm{dl}$ 以上を示 し腎機能障害が示唆される症例は 8 例あった.しかし， 今回の治療にてその数值が増悪した症例はなかった。 また，他の血液生化学，尿検査上，この療法に関する と考兄られる異常は観察されなかった。 また，治療に 関する副作用は観察されなかったが，痔を併発してい る症例にアンテナ捜入時の疼痛が観察された。

\section{IV. 考 寨}

高齢化社会を示す本邦において，前立腺肥大症など の排尿障害を示す症例は急速に増加しつつある。しか 
図 8 アンテナよりの電磁波の分布

電 界 分 布
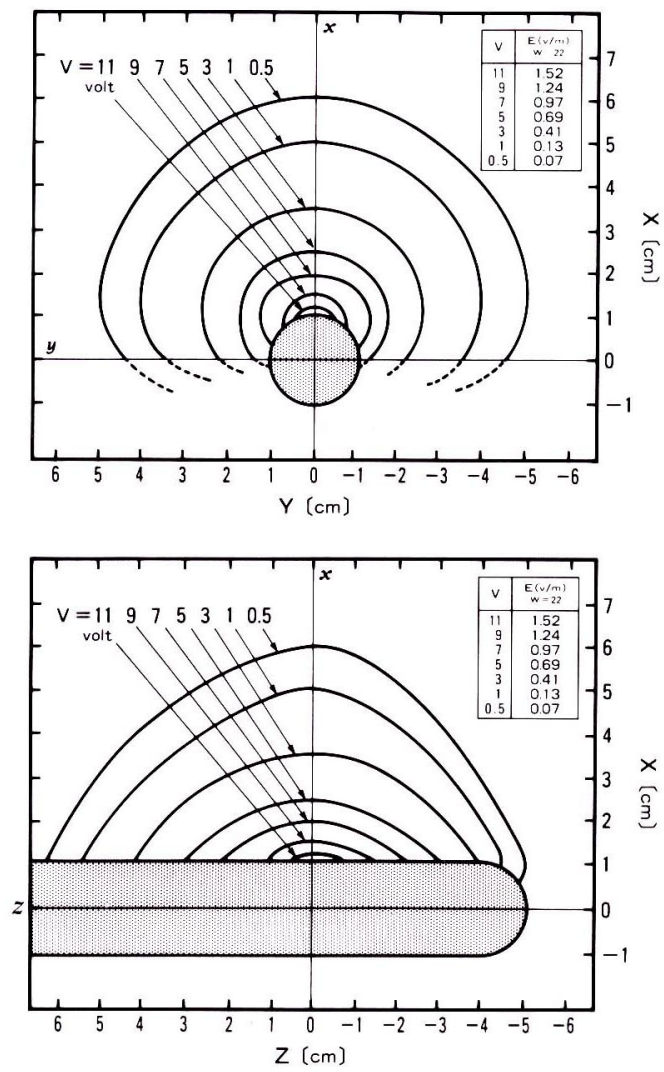

も, 食生活の欧米化に従い多くの全身性合併症を有す る症例も増光，必ずしも手術療法のみで対処できる訳 にはいかなくなりつつある。このような前立腺肥大症 に対する非観血的末たは保存的治療として, 前立腺凍 結術, 温熱療法, 尿道拡張術, 尿道内ステント留置 術1) (6)さらにホルモン剤や漢方薬を中心とした内服治 療などが検討され始めてきた。

温熱療法はさき汪ど述べたように $915 \mathrm{MHz}$ の電磁 波を用いた新しい治療法の一つとして注目をあびつつ あるが，一般には悪性腫瘍治療器として使用されてい

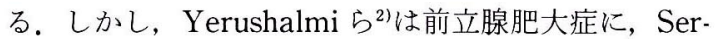
vadio $5^{3)}$ は前立腺肥大症や前立腺炎に，さらにVan $\mathrm{Erps}^{4)}$ は前立腺肥大症にこの機器を使用し治療を行 いすずらしい臨床成績を報告している。私たちも予 報としてその臨床成績を報告してきた ${ }^{8 / 9)}$ ．今回，30例 の前立腺肥大症症例での臨床成績を評価した。

1. 使用した機器及び治療条件について

今回の装置はベルギー製で，図 1 に示すように 915
図 9 ファントム実験における温度分布

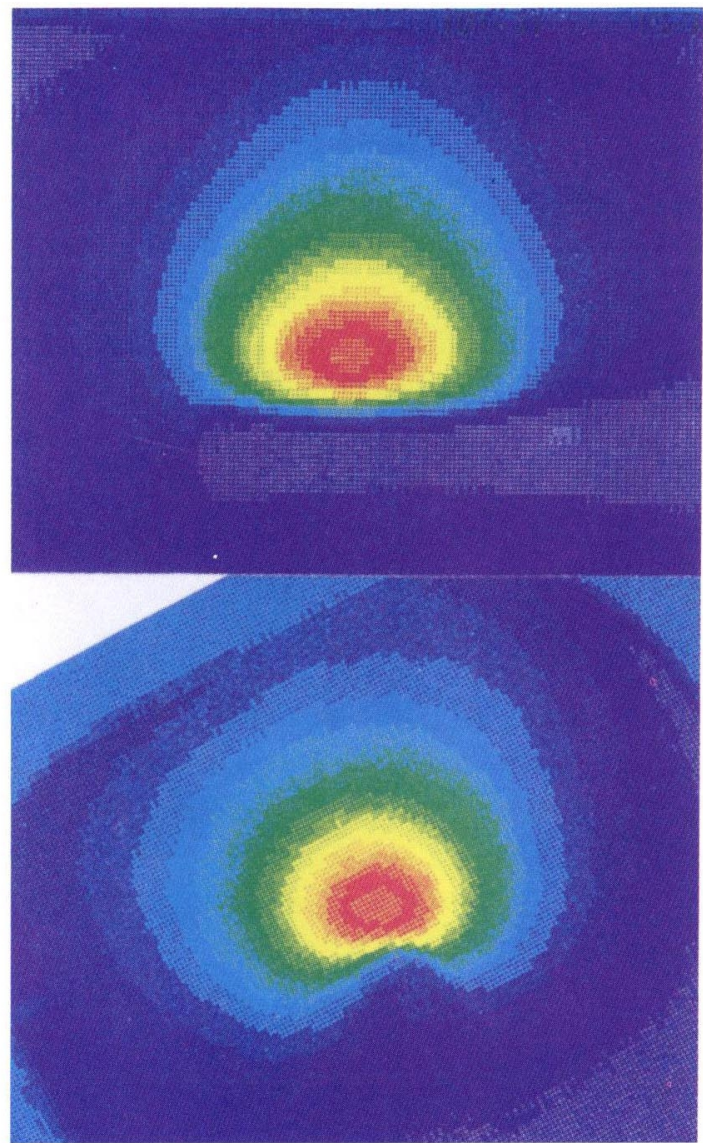

$\mathrm{MHz}$ の電磁波を発生するアンテナとそれを冷却する 装置, さらに温度管理や治療全体の管理を行らコン ピュータ装置からなっている。このうち使用したアン テナの性能について，共同研究者の一人である堤の検 討では, 電磁波はアンテナより一定の方向に分布して 抢り，その減衰曲線より判断すると精巣への影響はほ とんぞないものと考光られた ${ }^{10)}$ (図 8)。 また，ファン トムを用いて得られたサーモグラムより温度分布はほ 汴前立腺と一致しているのが観察された（図 9 )。

さて, 治療条件としては, Yerushalmi ら ${ }^{2)}$ の行って いる条件を参考にして行ったが，治療前の予備実験で 計算上の前立腺内温度が $43.5^{\circ} \mathrm{C}$ では尿道内温度が 39 か ら $40^{\circ} \mathrm{C}$ を, $45^{\circ} \mathrm{C} て ゙ は 41^{\circ} \mathrm{C}$ を示し, Prout の尿道および前 立腺内温度の測定結果 ${ }^{11}$ や V a E E r p らの尿道内温度 測定の結果 ${ }^{4}$ から，この機器を使用時の尿道内温度は 40 から $43^{\circ} \mathrm{C}$ に達し，これよりアンテナとの間にある前 立腺内温度は, 尿道内温度が $40^{\circ} \mathrm{C}$ 程度を示しても $42^{\circ} \mathrm{C}$ 
前後を示していると考兄られた。自他覚的にも非常に 改善が見られた点をも含めて考党ると，今回の治療条 件は十分前立腺内温度を高め，乙か子排尿障害を治療 しらる条件であると考皃た。

自覚症状のスコア值の減少と治療回数についてみる 之, 4 回治療後より昼間排尿回数, 夜間排尿回数, 尿 線の状態, 排尿遷延度, 排尿苯延度が改善し, 治療回 数を増すごとに良くなった。その後のスコア值は著し く減少しなかった点より考光ると, 温熱療法の回数は 少なくとも 4 回以上必要かと考兄られた。しかし，尿 閉症例において 6 回後判定でも排尿ができなかった症 例が10回施行後の判定にて排尿が可能となった点から みて，特にこのような症例の治療には少なくとも10回 以上行らのが好ましいと考えられた。

\section{2. 臨床成績について}

臨床成績としては自覚症状の面では漂㜔全員になん らかの程度にて改善が観察され，少なくとも 1 力月間 は持続していた。この成績は, Yerushalmi ら²)やVan Erps ら ${ }^{4)}$ が報告している成績とほぼ同様の結果であっ た。一方, 他覚的には残尿量の減少, 尿流量面での改 善4)などがあるとされて拉り，今回の検討した結果で も同様であった。

しかし、このような治療の評価を行うには諸々の問 題点が残っている。例えば他覚的評価としての尿流量 検查では検查を受ける者の精神的状態がその結果に反 映され易く，また自覚症状を症例の言葉のみで判断す ると客観性に乏しく評価に苦労するが，今回行った自 覚症状のスコア值化や尿流量検査のノモグラム使用の 評価は比較的客観的に評価しらる方法かと考光られ た．以上の要因にて委員会判定と主治医判定での有用 度との間に差が現れたものと考えられる。また，有用 度の評価成績についてみると，比較的よい成績であっ たが，その理由としては他覚的所見の評価に残尿量や 尿流量検查などウ口ダイナミックスを取り上げた点， さらに自覚症状の改善度を他覚的所見の成績とほぼ同 等とした判定基準を用いたためと考えられた。今後, 自覚症状面での改善については，二重盲検試験などを 行いながら，本治療の評価をする必要があると思われ た。

いずれにしても，本治療は自他覚症状・所見の改善 が見られ，また留置カテーテルのある症例の半数にカ テーテル抜去を行えたことより考えて見ると，排尿の “Quality of life”の面からみて非常に有用な治療法の 一つと考えられ，排尿障害を訴えている症例に対し，
図10 3 日間温熱療法施行後の前立腺組織像

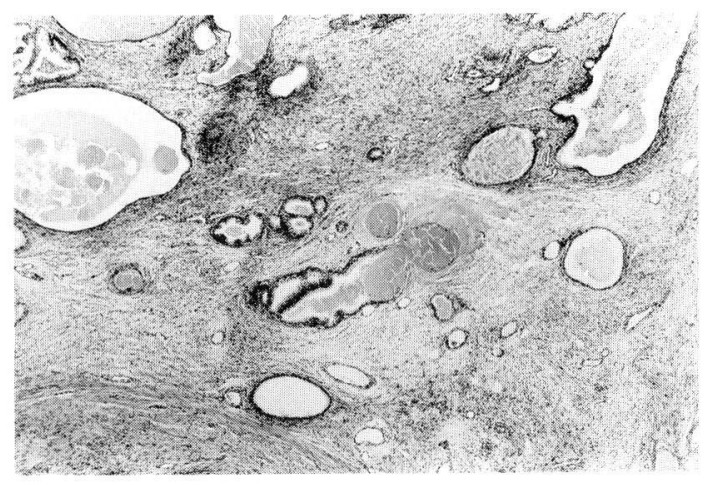

試みても良い治療法かと思われた。

さて，温熱療法が効果を示す機序はいまだ解明され ていない，現在，推測されているのは前立腺内にある $\alpha$-receptor の障害や平滑筇組織の障害, さらに前立腺 組織の血流が改善され代謝が正常化したとの考兑，さ らに温熱による微小血管の変化に伴う組織学的変化な どが考えられている。多くの場合は温熱による $\alpha$ receptor 障害などの機能的変化と考兄られるが，私た ちは前立腺摘出術を行う症例に 3 日間連続しての温熱 療法を行ったのち得られた前立腺組織像に腺上皮の凝 固壊死性变化や平滑筋や線維細胞などの間質に対する 変化などの像を得ており（図10)，また，間質の細胞か らの basic fibroblast grouth factor が前立腺上皮の増 殖に関与するとの Lawson ${ }^{12)}$ の意見などから判断する と, 温熱による器質的変化も症状改善に何等かの関与 をしているものと考えている，今後，症例を重叔て の療法の長期成績をも調べるとともに，治療効果発現 機序の解明もあわせて検討していく方針である。

\section{V. 結 語}

30例の BPH について経直腸的温熱療法装置の有用 性ならびに安全性，さらにその臨床成績を評価した。 自覚症状浪泳全員に改善が観察された。また, 留置 カテーテルのある症例の半数にカテーテル抜去が可能 であった，前立腺重量に治療前後で有意差は認められ なかったが，残尿量には明らかな減少傾向が観察され た。量大尿流量率や平均尿流量率にも一部の症例に明 らかな改善が見られた。以上より温熱療法は前立腺肥 大症による排尿障害に対する非観血的療法の一つとし て有用な方法と考えられた。

本論文の要旨の一部は第39回日本泌尿器科学会中部総会 (富山，1989), THE 8TH JOINT CONGRESS OF THE 
ASIAN-PACIFIC FEDERATIONS OF THE INTERNATIONAL COLLEGE OF SURGEONS (BANGKOK, 1989)及び前立腺温熱療法シンポジゥム(大阪, 東京, 1990) にて発表した。

\section{文献}

1) 安本亮二, 小早川等, 川喜多順二, 山本啓介, 前川 正信, 系井壮三：前立腺凍結術の実際とその問題 点. 泌尿紀要, 32, 1599-1604, 1986.

2) Yerushalmi, A., Singer, F.D., Reiner, I., Arielly, J., Abramovici, Y., Catsenelson, R., Levy, E. and Shani, A.: Localized deep microwave hyperthermia in the treatment of poor operative risk patients with benign prostatic hyperplasia. J. Urol., 133, 873-876, 1985.

3) Servadio, C., Leib, Z. and Lev, A.: Diseases of prostate treated by local microwave hyperthermia, Urology, 30, 97-99, 1987.

4) Van Erps, P.M., Dourcy, B.Z. and Denis, L.J. : Local hyperthermia in benign prostatic hyperplasia (BPH) (abstract), J. Urol., 143, 414a, 1990.

5) Castaneda, F., Reddy, P. and Wassermen, N.: Benign prostatic hypertrophy : retrograde transurethral dilatation of the prostatic urethra in humans. Radiology, 3, 649-653, 1987.

6) Nordling, J., Holm, H.H., Klaskov, P., Nielsen, K.K. and Andersen, T.: The intraprostatic spiral: A new device for insertion with the patient under local anesthesia and with ultrasonic guidance with 3 months of followup. J. Urol., 142, 756-758, 1989.

7) Siroky, M.B., Olsson, C.A., and Krane, R.J.: The flow rate monogram: II Clinical correlation, J. Urol., 123: 208-210, 1980.

8) 安本亮二, 秋田誠次, 清田敦彦, 上川視則, 浅井省 和, 河野学, 田部 茂, 浅川正純, 吉原秀高, 坂 本 亘, 井関達男, 仲谷達也, 岸本武利, 前川正信, 堤 四郎：前立腺肥大症に対する温熱療法の試 み, 日泌尿会誌，81，933, 1990.

9) Wada, S., Yasumoto, R., Kiyota, A., Kamikawa, S., Kishimoto, T, Maekawa, M., Kuroda, K. and Tsutsumi, S.: The experience of the transrectal hyperthermia for treating benign prostatic hyperplasia. abstract of the 8th joint congress of the asian-pacific federations of the international college of surgeons, 1989.

10）是 四郎：前立腺温熱治療システムPRIMUSの 生殖器に与方る影響に関する擬似実験結果, 1990.

11) Prout, G. and vanHooydonk, N.: Report on intra-operative mesurements of intraprostatic temperatures during transrectal thermal therapy, 1990.

12) Lawson, R.K.: Benign prostatic hyperplasia and growth factors, Urologe, $29: 5-7,1990$.

（1990年11月12日受理，特別掲載） 